\title{
Social impacts of the development of science, technology and innovation indicators
}

Citation for published version (APA):

Gault, F. (2011). Social impacts of the development of science, technology and innovation indicators.

UNU-MERIT, Maastricht Economic and Social Research and Training Centre on Innovation and Technology. UNU-MERIT Working Papers No. 008 https://doi.org/10.2139/SSRN.1949172

Document status and date:

Published: 01/01/2011

DOI:

10.2139/SSRN.1949172

Document Version:

Publisher's PDF, also known as Version of record

\section{Please check the document version of this publication:}

- A submitted manuscript is the version of the article upon submission and before peer-review. There can be important differences between the submitted version and the official published version of record.

People interested in the research are advised to contact the author for the final version of the publication, or visit the DOI to the publisher's website.

- The final author version and the galley proof are versions of the publication after peer review.

- The final published version features the final layout of the paper including the volume, issue and page numbers.

Link to publication

\footnotetext{
General rights rights.

- You may freely distribute the URL identifying the publication in the public portal. please follow below link for the End User Agreement:

www.umlib.nl/taverne-license

Take down policy

If you believe that this document breaches copyright please contact us at:

repository@maastrichtuniversity.nl

providing details and we will investigate your claim.
}

Copyright and moral rights for the publications made accessible in the public portal are retained by the authors and/or other copyright owners and it is a condition of accessing publications that users recognise and abide by the legal requirements associated with these

- Users may download and print one copy of any publication from the public portal for the purpose of private study or research.

- You may not further distribute the material or use it for any profit-making activity or commercial gain

If the publication is distributed under the terms of Article $25 \mathrm{fa}$ of the Dutch Copyright Act, indicated by the "Taverne" license above, 


\section{UNITED NATIONS \\ UNIVERSITY}

UNU-MERIT

\section{Working Paper Series}

\section{\#2011-008}

Social impacts of the development of science, technology and innovation indicators

By Fred Gault 


\section{UNU-MERIT Working Papers}

ISSN 1871-9872

Maastricht Economic and social Research and training centre on Innovation and Technology, UNU-MERIT

UNU-MERIT Working Papers intend to disseminate preliminary results of research carried out at the Centre to stimulate discussion on the issues raised. 


\title{
Social Impacts of the Development of Science, Technology and Innovation Indicators
}

\author{
Fred Gault \\ gault@merit.unu.edu \\ UNU-MERIT, Maastricht, The Netherlands \\ and the Tshwane University of Technology (TUT) \\ Institute for Economic Research on Innovation (IERI), Tshwane, South Africa
}

\begin{abstract}
This paper examines the social impacts of the development of science, technology and innovation indicators. The approach deals separately with the development process and with the use of the indicators that result. Underlying the discussion is an assumption that indicators are a technology, a product, which governs behaviour, is modified by users (outside of the producer community), and develops in response to user needs. Science and technology indicators are considered separately from innovation indicators, and the importance of language based on codified and tacit knowledge is emphasized. The knowledge is codified in manuals, and the tacit knowledge is held in overlapping communities of practice that develop the manuals, gather the data, produce the indicators and use them. Finally, there is a discussion of how this process changes and renews itself.
\end{abstract}

JEL Codes

O33, Z13

Key words

Economic and social impacts, innovation indicators, science and technology indicators, indicators and social constructs

February 2011 



\section{Introduction}

This paper examines the social impacts of the development of science, technology and innovation indicators. The examination deals separately with the development process and with the use of the indicators that result. Underlying the discussion is an assumption that indicators are a technology, a product, which governs behaviour, is modified by users (outside of the producer community), and develops in response to user needs.

The discussion begins with a well known example; the indicators that are part of the System of National Accounts (SNA). A review of how these indicators have been created, how they evolve and how their use has social, as well as economic, impact provides a framework for assessing science, technology and innovation indicators. As science and technology, and science systems, are quite different from innovation and innovation systems, the two topics are addressed separately

The objective is to show that indicators, of any kind, are developed as a result of a perceived need of the community that wants to use them and both the development process and the eventual use of the indicators have social impacts. The development process involves consensus building and the establishment of a common language, with an agreed vocabulary and grammar, which facilitates the discourse which is part of the development and evolution of the indicators. These activities have an impact on the community of practice as it learns to use the language and to advance the subject. Once the indicators are produced, their use and the use of the language that describes indicators, have social impact. There is also feedback from the users to the producers which contributes to further evolution of the indicators. The two level approach to the analysis of indicator development and of indicator use persists through the paper.

There is a similarity in these activities with those in an organization, or firm, that produces new or significantly improved products (goods or services) or processes (transformation or delivery processes, organizational processes or those resulting from the use of business practices, or market development). The producer of indicators for public use is usually an international organization or supranational organization such as the United Nations or the European Union. Users are just about every institution in the society, including individuals. As a result of using the indicators users may change their behaviour and may provide suggestions for revision to the indicators. The role of the user is fundamental in this process and is similar to that of the user in an innovation system. The user can provide information that leads the producer to improve the product, the user can collaborate with the producer on new products, or the user can create a new product and transfer it to the producer, produce it independently or publish the methodology for any organization to use.

In the case of user innovation, there is a fourth possibility which is that the user that has created a new product or modified an existing one does nothing but benefit from its use and the knowledge is not transferred to the broader community of practice. This fourth case does 
not arise in indicator development for public use, as indicators are developed to be used by a community. Indicators that are not used are not indicators.

The next section presents the System of National Accounts as an example of indicator production and use and leads to a discussion in Section 3 of indicators of science, technology and innovation (STI). Section 4 then deals with the use of STI indicators and their impact. Section 5 provides a research agenda and the paper is summarized in Section 6.

\section{An Example of the Development of Indicators}

The System of National Accounts (SNA) is well established at all of the levels discussed in this paper: manual production; information gathering; and, the production and use of indicators. The SNA can be seen as a model for the discussion which follows.

\subsection{The System of National Accounts}

The SNA provides a model of the development of indicators , their use and their impacts. National accounts provide the means of estimating stocks and flows in the economy and they give rise to a set of well known indicators, such as Gross Domestic Product (GDP), the Consumer Price Index (CPI), the inflation rate, exchange rate, trade figures and unemployment figures. The indicators arising from the SNA have been in place for more than fifty years are now part of economic and social discourse in the society, not just in the community of practice that produces the indicators.

As the indicators evolved, social discourse changed and economic agents were better placed to respond to changes in the values of the indicators. A rising exchange rate, for example, might trigger foreign purchasing of the domestic currency, while high inflation could result in its sale. As the indicators became better known, they entered day to day conversation with comments on GDP, interest rates, the CPI, unemployment or inflation being part of day to day life.

STI indicators are not yet part of day to day conversation, as they are a much more recent occurrence. The current version of the System of National Account, the 2008 SNA (European Union et al. 2009), is an updated version of the 1993 SNA (European Union et al. 1994). It is the fifth version of the SNA, the first of which was published over fifty years ago.

The SNA Manual was prepared by a team of experts managed by one supranational organization and four international organizations . They are the: Statistical Office of the European Union (Eurostat); International Monetary Fund (IMF); Organisation for Economic Co-operation and Development (OECD); United Nations Statistics Division and regional commissions of the United Nations Secretariat; and the World Bank. The five organizations jointly published the 2008 SNA Manual (http://unstats.un.org/unsd/nationalaccount/sna2008.asp). 


\subsection{The Role of the Manual}

Manuals are guidelines for the collection and interpretation of data and for international comparisons of data, statistics and indicators. They are codified knowledge, knowledge that can be written and learned.

Manuals, in the world of indicators used for international comparisons, are supported by an international infrastructure. This includes the support of professional secretariats and the provision and maintenance of classification systems. Three examples, of many classifications, are given. They are: ISIC, ISCED and ISCO.

ISIC is the International Standard Industrial Classification of all Economic Activities, currently in its fourth revision although most countries and international organizations still use the third revision of which there are two versions (http://unstats.un.org/unsd/cr/registry/isic-4.asp). ISCED is the International Standard Classification of Education (http://unstats.un.org/unsd/class/family/family2.asp?Cl=223). And, ISCO-88 is International Standard Classification of Occupations (http://www.ilo.org/public/english/bureau/stat/isco/index.htm).

Manuals provide a language of discourse and they behave like a technology, the assumption made in the Introduction (Gault and McDaniel 2002). Manuals change behaviour as they provide definitions, examples, and applications and encourage people and organizations to follow their direction. As a result, international comparisons are possible. Cowan, David and Foray (2000) warn of the possibility of 'lock in' to obsolete conceptual schemes as a result of codification, but this is avoided by the regular revision of the manual.

\subsection{SNA Indicators}

Indicators are statistics, or a combination of statistics, that are populated by data. Social and economic data can come from a variety of sources including surveys, administrative data or registers, and case studies. Indicators suggest, or indicate, a characteristic of a system and indicators can mislead.

The example in this section is the GDP which is arrived at by taking data from a wide range of industrial surveys and imputing data from other sources when survey data are not available. The result, GDP, is an indicator of the size of the economy and its change over time is an indicator of economic growth or decline. Neither are indicators of social progress or of wellbeing. GDP can be combined with other indicators, such as population, to give GDP/Capita. GDP/Capita is an example of an indicator that can mislead. It is used for ranking countries and the assumption is that a high ranking is good. However, two countries with a high ranking, such as Norway or the United States, could have quite different income distributions (CIA 2010). The caveat that this illustrates is that no decision or policy should be based on just one indicator. 
While the development of the indicators that are part of the SNA change social discourse, once the indicators are defined and understood, the values of the indicators themselves change the lives of people. These changes may result from personal decisions such as leaving a region with high unemployment or as a result of a government policy to subsidize training and development of the workforces. In times of recession, defined by some as a decline in GDP for two or more successive quarters, public expenditure and employment may be reduced, currencies can adjust and aid budgets fall. In some parts of the world, lives depend on aid. Policy intervention, based on evidence from indicators, changes the lives of people.

To make the link to science, technology and innovation, the expenditure on research and development (R\&D), which had from the beginning been regarded as an expense, was capitalized in the SNA 2008. This makes R\&D part of capital formation in the SNA once the SNA 2008 is implemented. Current work on the role of intangible investments in the economy demonstrates that the SNA continues to evolve.

\section{Science, Technology and Innovation}

As the subject is the social impact of the development of indicators, a first step will be to separate science and technology from innovation, so that the different characteristics of the two subjects can be considered.

\subsection{Science and Technology}

Science and technology activities deal with formal knowledge generation. The formal knowledge is created through research and development in higher education and research institutes, in R\&D units in business (usually, but not always, larger businesses), in government laboratories and in private non-profit institutes (which tend more to fund than to do R\&D).

The funding for basic R\&D comes from government through direct or indirect support, from higher education institutions and research institutes and may also come from private nonprofit organizations with specific interests such as health research. Some is funded by business. However, the principal source is through granting councils and a competitive process.

Applied research and development is also funded directly or indirectly by government but a significant source of funds will be the businesses themselves. There are also technology transfer activities connecting higher education, government laboratories and the private sector.

Some of the flows of funds result from policies for science and technology produced by ministries of research, education, innovation, technology or a combination of those words. There is a long history of science and technology policy and of support for research and development and those doing the science are part of the process. Scientists and engineers do 
research, sit on granting councils, engage in the peer review process either as applicants for grants, or reviewers or both. They receive grants and contracts, and manage research in public and private sector. They are not without influence and they are present in all parts of the system except, perhaps, at the level of policy making.

Indicators of R\&D are well established and used. As with the SNA, the evolution of the indictors from the first Frascati Manual in 1963 (OECD 1963) has altered the discourse around R\&D activities and their assessment. At the marco level, the Frascati Manual has provided the guidelines necessary to collect and to interpret R\&D performance and funding data and to estimate the gross domestic expenditure on R\&D (GERD). This indicator, divided by GDP, the GERD/GDP ratio, has been the subject of targets set by governments or the European commission and the targets change the behaviour of the research community and those implementing science and technology policy.

As the means of measuring R\&D performance and funding has become established, it has become possible to identify R\&D in particular areas such as bio fuels, energy, genetically modified foods, software, and other areas of policy interest. In some cases, this information can result in debates on the ethics of the research.

The point here is that the language used for the development of R\&D indicators has evolved over the last half century from the first edition of the Frascati Manual to the sixth (OECD 2002) and the resulting indicators have made possible policy interventions which have altered behaviour of practitioners and of the public which is either a supporter of $R \& D$ through taxes or a user of the outcomes of R\&D.

\section{Science and Technology Manuals, Surveys and Indicators}

Measures of R\&D are not the only indicators of science and technology activity. In addition there are patent statistics, governed by the OECD Patent Statistics Manual (OECD 2009a), now in its second edition and providing guidelines on how to work with 'triadic families' of patents. There are bibliometric ${ }^{1}$ indicators concerning scientific papers, their publication, citation, and their co-publication (Davignon, Gingras and Godin 1998). In this case, there is no manual providing accepted guidelines for the collection, interpretation and dissemination of data on publication. Another area not explicitly covered by manuals is the use and planned use of technologies and practices.

In the first and second editions of the Oslo Manual (OECD 1992, OECD/Eurostat 1997), there was reference to data on the use and planned use of technologies but that explicit reference was not present in the third edition (OECD/Eurostat 2005). Technology use was still present, but it was part of the novelty classification of innovation. Purchasing technology that was not a new or significant improvement on the existing process technology was not

\footnotetext{
${ }^{1}$ Bibliometric analysis is done in an number of organizations, such as the Obervatoire des sciences et des technologies, Montreal, Canada (http://www.ost.uqam.ca/Observatoire/tabid/56/language/en-US/Default.aspx), and the Forshungscentrum Jülich, Jülich, Germany (http://www.fz-juelich.de/zb/Bibliometrics/)
} 
innovation, but if the purchase was new to the firm, it was process innovation at that entry level of novelty.

The use of management processes never appeared in the Oslo Manual until the third edition when the definition was expanded to include organizational change and the use of business practices. Some experience supporting this came from an OECD project on the use of knowledge management in firms (OECD 2004). Among other things, the work demonstrates that practices, their use and planned use, can be studied in the same way as technologies.

Another area of science and technology indicator development concerns human resources. The Frascati Manual deals with data on researchers, and data collected supports indicators published in the Main Science and Technology Industries (MSTI) (OECD 2010a). However not all scientists and engineers do research. Interest in indicators of human resources for science and technology (HRST) gave rise to the Canberra Manual (OECD/Eurostat 1995). More recent work has addressed the career paths of doctorate holders (Auriol, Felix and Schaaper 2010) and that continues to evolve.

Patents and bibliometric data come from public and proprietary data bases. There have been surveys of technology use including manufacturing technology, biotechnology and nanotechnology, and of practices, such as knowledge management. They produce data and have the potential to produce indicators, such as the propensity to use the technologies or practices by industry, region, or size of firm.

\subsection{Innovation}

Indicators of the activity of innovation are not as well developed as those for R\&D. However, their development has greater potential for social impact because innovation is not confined to the laboratory, it is a market place phenomenon and has more immediate impact than $R \& D$ that can take years to effect change through innovation.

The definition of innovation used for this discussion is taken from the Oslo Manual. An innovation is the implementation of a new or significantly improved product (good or service), or process, a new marketing method, or a new organizational method in business practices, workplace organization or external relations OECD/Eurostat (2005, para 146).

'Implementation' in the definition connects innovation to the market.

Box 1 provides a brief history of the evolution of the manual, which includes the Bogotá Manual and its evolution. A characteristic of this evolution has been the recognition that innovation is not an isolated phenomenon and, as a consequence, a systems approach to its description is needed. 


\section{BOX 1: Short history of the development of innovation indicators}

1980s

Nordic Council, U.S., others

Experimental surveys.

1990s

Voorburg Group works on services statistics and innovation in services. UN City Group (www.voorburggroup.org).

Work leading up to the first edition of the Oslo Manual (OECD 1992)

Product and process innovation in manufacturing.

Work leading up to the first Community Innovation Survey (CIS) for reference year 1992. CIS and CIS-like surveys are done repeatedly in many countries.

1995 - 1997 revision of the Oslo Manual leading to the second edition

(OECD/Eurostat 1997). The coverage of the manual was extended to include service industries.

1996 OECD Blue Sky Forum I

Among other things, it introduced a systems approach to the understanding

of innovation (OECD 2001).

2000s

2000 Bogota Manual (RICYT/OEA/CYTED 2001) introduced by RICYT to deal with innovation in developing countries in Latin America and the Caribbean. It covered manufacturing.

2002 - 2005 revision of the Oslo Manual leading to the third edition (OECD/Eurostat 2005). The definition was expanded to add organization change and business practices and market development. The systems approach was adopted and reflected in a chapter on linkages.

2004 RICYT proposed an Annex to the Oslo Manual interpreting it for use in developing countries. The UNESCO Institute of Statistics (UIS) co-ordinates the preparation of the Annex which is added to the Oslo Manual in 2005.

2006 OECD Blue Sky forum II

Emphasize work on micro data, on analysis of outcomes and impacts as well as inputs, and on telling the story to the policy makers based on the analysis of innovation data (OECD 2007).

2007 AU/NEPAD adopt the Oslo and Frascati Manuals for use in surveys.

2007-2010 OECD Innovation Strategy (OECD 2010b, 2010c) developed along with a measurement agenda (OECD 2010d).

2010s

2010 RICYT begins revision of the Bogota Manual to include service industries and agriculture.

2010 NESTI starts the implementation of the measurement agenda (OECD 2010d).

2010 On-going work on new areas: public sector, open, social and user innovation. 
The systems approach is implicit in the both the Oslo Manual and in the OECD Innovation Strategy (OECD 2010b, 2010c, 2010d). Simply put, actors or economic agents engage in activities, are linked to other actors, and the activities and linkages give rise to outcomes and longer term impacts.

Actors include governments, education and health institutions, business, and foreign institutions. Some of the activities that they engage in are $R \& D$, invention, innovation, diffusion of technologies and practices, and human resource development. There are many forms of linkage. Some are contracts, collaborations, co-publication and grants. Monitoring of one part of the system by another is also a linkage measure. As a result of the activities and linkages of the actors, there are short term outcomes, such as jobs and growth, and longer term impacts, such as well being, cultural change of global influence.

The activity of innovation is dynamic, complex, non-linear and global. This means that there is no equilibrium, dynamic or static, as new things are happening and changing the economy and the society. The innovation system is complex, and therefore difficult to understand, but see OECD (2009b) for approaches for dealing with complexity. The non-linearity of the system results from the positive and negative feedback loops provided by the linkages. In a non-linear system a linear change of a policy intervention, such as the percentage of R\&D spending that is allowed as a tax deduction. Moving it from 10 to 15 to 20 to 25 percent does not necessarily result in a corresponding increase of 5 per cent of the total value of the claims. More than one policy intervention can lead to unexpected or undesired outcomes in a non-linear system. Finally, innovation is global and is influenced by activities outside of the country. As a result innovation policy is limited in what it can change (Gault 2010).

The innovation community is more difficult to describe than the S\&T community. It includes the people in firms that innovate without doing R\&D, as well as many, but not all, entrepreneurs, and staff from many parts of large firms, not just the R\&D department. Both S\&T and innovation activities can be measured, but measuring the activity of innovation, and innovation activities, present challenges and some of these are addressed in the Oslo Manual.

\section{Innovation Manuals, Surveys and Indicators}

Manuals provide the concepts and definitions for the variables to be measured in surveys or by other means. Ideally, the manual is operationalized by the survey but it is rare that all the variables discussed in the manuals are found in surveys. An example is design which was present in all three editions of the Oslo Manual, but which was not well covered in the early versions of the CIS. This gap was addressed in CIS 2008, conducted in 2009 for the period 2006-2008.

Manuals are codified knowledge which provides guidance, but their effective use depends on tacit knowledge present in the community of practice that produces the manuals, in the teams that do the surveys that collect the data, or integrate survey data with administrative data, or use insights from case studies. The balance between codified knowledge and tacit knowledge presents an on-going tension. When tacit knowledge dominates, it is time to revise the 
manual to provide a new platform of accepted codified knowledge and the language that goes with it.

Box 1 provides a short history of innovation surveys and more can be found on the earlier versions of the CIS in Arundel et al. (2008). The surveys produce the data that populate the statistics that give rise to the indicators that describe the activity of innovation, innovation activities, and other characteristics of the firm that made the resulting data set more analytically useful. The indicators are then presented in country reports or in scoreboards such as the European Innovation Scoreboard 2009 (EIS) (Pro Inno Europe 2010), the OECD Science, Technology and Industry Score Board (OECD 2009c) and RICYT (2010). With the adoption of Europe 2020 Innovation Union policy, the EIS has been revised to become the Innovation Union Scoreboard (IUS). The IUS 2010 is available at Pro Inno Europe (2011).

\section{STI Indicators and impacts}

Indicators of R\&D expenditure and of the human resource involved in R\&D have had impact over the years and the Lisbon target of a GERD/GDP ratio of 3 per cent is the prime example. In the domain of innovation indicators there is nothing comparable, but some progress is being made.

\subsection{Use}

The various scoreboards are not yet as comprehensive as the reports produced by the System of National Accounts for most countries, which are used for policy input and for international comparisons. The problem of the use of indicators of innovation is reviewed by Arundel (2007) and remains a problem.

Indicators support monitoring, benchmarking, foresight and, research into further development of indicators. For R\&D, the most aggregate level of monitoring consists in observing the GERD/GDP ratio and making comparisons of change over time. This can also lead to benchmarking in the form of target setting as a goal or as part of becoming more like a more successful comparable country. In the case of innovation, there is no comparable indicator, in part, because the gross domestic expenditure on innovation is not yet a robust indicator. Using the propensity to innovate requires a comparable measure for all countries to be compared, a problem which has never been overcome for the propensity to do R\&D.

The need to have an indicator for innovation comparable to the GERD/GDP ratio for R\&D moved the EU Commissioner for Research and Innovation to convene a high-level panel of experts to produce just this (DG Research and Innovation 2010). In the end, what the panel did was to offer two options. The first was a list of three indicators: patent applications weighted by GDP, percentage of employment in knowledge intensive activities and, the contribution of 'innovative-related trade' in manufactured goods to the balance of trade in goods. The second was a single indicator, the share of fast growing innovative firms in the economy, which would require two years of work to produce the needed data. 
The report ended with an agenda for further work, including improving the current systems for measuring innovation, measuring new forms of innovation, further work on understanding innovation, and making better use of innovation indicators and statistics. The decisions were left to the Commissioner. The whole process of the convening and the reporting of the High-Level Panel was a good example of the political level entering the domain of indicator development.

\subsection{Policy impacts}

As the indicators expand and policy makers recognize that innovation is not an isolated event, more attention is being given to the framework conditions and the policy mix that helps the system to work better. As more micro data analysis is done, the important result that the propensity to innovate in firms is higher than the propensity to do R\&D will have more influence on policy. An R\&D tax benefit is of no use to an innovative firm that does no $\mathrm{R} \& \mathrm{D}$, but support for capital investment in ICTs, may be, or a voucher programme allowing the firm to access knowledge from universities and colleges to help in the solving of problems related to innovation. Such policies, based on the empirical evidence provided by the indicators, change the behaviour of people and of firms and how they learn.

\section{Where now?}

Indicator development is a dynamic activity. The OECD Innovation Strategy (OECD 2010b, 2010c) included a Measurement Agenda (OECD 2010d) which is now being implemented. It includes intentions to:

- Improve the measurement of broader innovation and its link to macro-economic performance;

- Invest in high-quality and more comprehensive data infrastructure to measure the determinants and impacts of innovation;

- Recognize the role of innovation in the public sector and promote its measurement;

- Promote the design of new statistical methods and interdisciplinary approaches to data collection; and,

- Promote the measurement of social goals and social impacts of innovation.

This agenda is rooted in the outcomes of the OECD Blue Sky II Forum (OECD 2007) which stressed the importance of micro data analysis, greater emphasis on output measures of STI activities and the importance of using indicators to tell a story to policy makers, which underlies the last point in the agenda. However there has been a shift in emphasis when it comes to influencing policy makers.

At the OECD Blue Sky II Forum in 2006 the science advisor to the U.S. President of the day, John Marburger (Marburger 2007), suggested that the equivalent of the Minister of Industry, or Science and Technology, should receive advice comparable to that received by the equivalent of the Minister of Finance, based on complex and intimidating models. In 
Measuring Innovation, A New Perspective (OECD 2010d) the recommendation is "that survey and administrative data need to be aligned with aggregate economic measures and become a visible part of the System of National Accounts (SNA). The goal is to help recognize the important role of STI policies in promoting economic growth". The link to economic growth moves the policy advice to the equivalent of the Minister of Finance who tends to be more powerful than a science minister.

In the African Union, the second phase of its survey measurement programme for R\&D and innovation has been approved and will build on the results reported in the African Innovation Outlook (AU 2010). As part of this a community of practice has evolved which will share knowledge with countries new to the programme and building, as a consequence, an African NESTI.

In Latin America and the Caribbean, RICYT is adding the service sector and the agricultural sector to the Bogotá Manual (RICYT/OEC/CYTED 2001). The work on agriculture fits well with a renewed interest in agriculture as a knowledge-based industry (Kraemer-Mbula and Wamae 2010) and is being promoted by Calestous Juma in Africa (Juma 2011 and OECD 2009d).

In South East Asia, the first meeting of an ASEAN NESTI has taken place and more work on the development and use of indicators in the region is expected.

As appropriate for a dynamic subject, the techniques for developing and analysing indicators of STI are advancing, the areas of coverage using existing definitions are expanding, of which innovation in agriculture is an example and other boundaries are being pushed. An example of boundary pushing is an examination of the place of the market in innovation. This has implications for understanding and measuring innovation in the public sector, among user innovators, and in the social context.

In the case of the public sector a health, education or social service provider can do all of the innovation activities found in the Oslo Manual and offer new or significantly improved products to their user communities. The problem is that the mechanism for transferring the product to the consumers is not the market. In user innovation, a user which can be a firm or an individual consumer, can create or improve a product. If the prototype is offered to a producer it appears in the innovation statistics as user innovation. If the innovator starts a firm, the new product is also captured in the innovation statistics as a producer innovation. However, if the knowledge needed to produce the new product is offered to a peer group, there is no market transaction and the activity is not registered in innovation statistics. Finally, there is the concept of social innovation in which communities solve problems and the market is not present. These three examples suggest that a broader conceptualization of the market in the definition might be an important topic for future work.

Another area for new work is the science of science and innovation policy (HusbandsFeeling et al. 2011) which is linked to Marburger's call for a new cross-cutting social science (Marburger 2007). However the need may be for separate sciences of science policy and of 
innovation policy (Gault 2011). The OECD is developing tools to support this kind of policy analysis (OECD 2010e). As this work evolves so will a new discourse and a community of practice with social implications and as the new social sciences produce significant findings which influence policy there will be broader social impact.

\section{Conclusion}

This paper has been about the social impacts of the development of STI indicators. The points have been made that the development of indicators is a social process with norms evolving as a result of the interactions of a community of practice, such as NESTI members. The users of the indicators also form communities of practice, within government departments and internationally as part of the policy process. And finally, decisions are made as a result of changes in the indicators which have considerable impact on people, firms, regions and countries. An important aspect of this work is that it is dynamic, changing emphasis in response to economic and social conditions, expanding the domain of discourse through extending coverage of sectors or revising the concepts and definitions that underlie the measurement, analysis and social impact.

\section{Acknowledgement}

This paper results from a presentation and discussions at the Conference on Social Demands and New Trends in Science and Technological Information held in Madrid, October 5-6, 2010. The support of RICYT is acknowledged as are the contributions of the participants in the session on the Social Impacts of the Development of Science, Technology and Innovation Indicators.

\section{References}

African Union (2010), Africa Innovation Outlook 2010, Tshwane: African Union.

Arundel, Anthony (2007), 'Innovation Survey Indicators: What Impact on Innovation Policy?' in OECD (2007a), Science, Technology and Innovation Indicators in a Changing World: Responding to Policy Needs, Paris: OECD, pp. 49-64.

Arundel, Anthony, Cati Bordoy, Pierre Mohnen and Keith Smith (2008), 'Innovation surveys and policy: lessons from the CIS', in Claire Nauwelaers and René Wintjes (eds), Innovation Policy in Europe, Measurement and Strategy, Cheltenham, UK and Northampton, MA, USA: Edward Elgar, pp. 3-28.

Auriol, Laudeline, Bernard Felix and Martin Schaaper (2010), 'Mapping Careers and Mobility of Doctorate Holders: Draft Guidelines, Model Questionnaire and Indicators (2 ${ }^{\text {nd }}$ ed.)', The OECD/UNESCO Institute for Statistics /Eurostat Careers of Doctorate Holders Project, STI Working Paper 2010/1, Paris: OECD. 
CIA (2010), The World Factbook, Washington: CIA (www.cia.gov/library/publications/theworld-factbook/index.html).

Cowan, R. P.A. David and D. Foray (2000), 'The Explicit Economics of Knowledge Codification and Tacitness’, Industrial and Corporate Change, 9, 221-251.

Davigon, Louis, Yves Gingras and Benoit Godin (1998), Knowledge Flows in Canada as Measured by Bibliometrics, Ottawa: Statistics Canada (www.statcan.gc.ca/pub/88f0006x/88f0006x1998010-eng.pdf ).

DG Research and Innovation (2010), Elements for the Setting-up of Headline Indicators for Innovation in Support of the Europe 2020 Strategy, Report of the High Level Panel on the Measurement of Innovation established by Ms Máire Geoghegan-Quinn, European Commissioner for research and Innovation, Brussels: DG Research and Innovation (http://ec.europa.eu/commission_2010-2014/geoghegan-quinn/hlp/documents/20101006-hlpreport_en.pdf ).

European Union, International Monitory Fund, Organization for Economic Co-operation and Development, United Nations, World Bank (1994), System of National Accounts 1993, New York: United Nations.

European Union, International Monitory Fund, Organization for Economic Co-operation and Development, United Nations, World Bank (2009), System of National Accounts 2008, New York: United Nations.

Gault, Fred (2010), Innovation Strategies for a Global Economy, Development, Implementation, Measurement and Management, Cheltenham: Edward Elgar and Ottawa: IDRC.

Gault, Fred (2011), 'Developing a Science of Innovation Policy Internationally', in Kaye Husbands Fealing, Julia Lane, John Marburger, Stephanie Shipp and Bill Valdez (eds) (2011), Science of Science Policy: A Handbook, Palo Alto: Stanford University Press, pp. 156-182.

Gault F.D. and S. McDaniel (2002), 'Continuities and Transformations: Challenges to Capturing Information about the 'Information Society', First Monday, Vol. 7, no. 2, Feb. 2002 pp. 1-13.

Husbands Fealing, Kaye, Julia Lane, John Marburger, Stephanie Shipp and Bill Valdez (eds) (2011), Science of Science Policy: A Handbook, Palo Alto: Stanford University Press.

Juma, Calestous (2011), A New Harvest, Agricultural Innovation in Africa, New York: Oxford University Press. 
Kraemer-Mbula, Erika and Watu Wamae (eds), (2010), Innovation and the Development Agenda, Paris: OECD and Ottawa: IDRC.

Marburger, John (2007), 'The Science of Science and Innovation Policy', in OECD, Science, Technology and Innovation Indicators in a Changing World: Responding to Policy Needs, Paris: OECD, pp. 27-32.

OECD (1963), Proposed Standard Practice for Surveys of Research and Development: The Measurement of Scientific and Technical Activities, Directorate for Scientific Affairs, DAS/PD/62.47, Paris: OECD.

OECD (1992), OECD Proposed Guidelines for Collecting and Interpreting Technological Innovation Data: Oslo Manual, Paris: OECD.

OECD (2001), Science, Technology and Industry Review, Special Issue on New Science and Technology Indicators, No. 27, Paris: OECD.

OECD (2002), Frascati Manual, Proposed Standard Practice for Surveys on Research and Experimental Development, Paris: OECD (www.oecd.org/sti/frascatimanual ).

OECD (2007), Science, Technology and Innovation Indicators for a Changing World, Responding to Policy Needs, Paris: OECD.

OECD (2009a), OECD Patent Manual, Paris: OECD.

OECD (2009b), Global Science Forum, Report on Applications of Complexity Science for Public Policy: New Tools for Finding Unanticipated Consequences and Unrealized Opportunities, Paris: OECD.

OECD (2009c), Science, Technology and Industry Scoreboard 2009, Paris: OECD.

OECD (2009d), Growing Prosperity, Agriculture, Economic Renewal and Development, DCD/DAC(2009), 36, Paris: OECD.

OECD (2010a), Main Science and Technology Indicators, Vol. 2010, Issue 1, Paris: OECD.

OECD (2010b), Ministerial Report on the OECD Innovation Strategy, Innovation to Strengthen Growth and Address Global and Social Challenges - Key Findings, Paris: OECD (www.oecd.org/innovation/strategy).

OECD (2010c) The OECD Innovation Strategy, Getting a Head Start on Tomorrow, Paris: OECD.

OECD (2010d), Measuring Innovation, A New Perspective, Paris: OECD. 
OECD (2010c), Ministerial report on the OECD Innovation Strategy, Innovation to strengthen growth and address global and social challenges - Key Findings, Paris: OECD (www.oecd.org/innovation/strategy ).

OECD (2010e), OECD Science, Technology and Industry Outlook 2010, Paris: OECD.

OECD/Eurostat (1995), The Measurement of Human Resources Devoted to Science and Technology - Canberra Manual, Paris: OECD.

OECD/Eurostat (1997), Proposed Guidelines for Collecting and Interpreting Technological Innovation Data: Oslo Manual, Paris: OECD.

OECD/Eurostat (2005), Oslo Manual, Guidelines for Collecting and Interpreting Innovation Data, Paris: OECD (www.oecd.org/sti/oslomanual).

Pro Inno Europe (2010), European Innovation Scoreboard (EIS) 2009, Pro Inno Paper No. 15, Brussels: DG Enterprise and Industry (www.proinno-europe.eu/metrics).

RICYT/OEA/CYTED (2001), Standardization of Indicators of Technological Innovation in Latin American and Caribbean Countries: Bogotá Manual, Buenos Aires: RICYT.

RICYT (2010), State of Science. Main Science and Technology Indicators, Buenos Aires: RICYT (www.ricyt.org/index.php?option=com_content\&view=article\&id=211:el-estado-dela-ciencia-2010\&catid=6:publicaciones\&Itemid=7 ). 



\section{The UNU-MERIT WORKING Paper Series}

2011-01 Mitigating 'anticommons' harms to research in science and technology by Paul A. David

2011-02 Telemedicine and primary health: the virtual doctor project Zambia by Evans Mupela, Paul Mustard and Huw Jones

2011-03 Russia's emerging multinational companies amidst the global economic crisis by Sergey Filippov

2011-04 Assessment of Gender Gap in Sudan by Samia Satti Osman Mohamed Nour

2011-05 Assessment of Effectiveness of China Aid in Financing Development in Sudan by Samia Satti Osman Mohamed Nour

2011-06 Assessment of the Impacts of Oil: Opportunities and Challenges for Economic Development in Sudan by Samia Satti Osman Mohamed Nour

2011-07 Labour Market and Unemployment in Sudan by Samia Satti Osman Mohamed Nour 2011-08 Social impacts of the development of science, technology and innovation indicators by Fred Gault 